\title{
The 5E Learning Cycle Model as Development of Booklet Teaching Materials at SMK BM Panca Budi 2 Medan
}

\author{
Rini Siti Jummiah ${ }^{1}$, Saidun Hutasuhut ${ }^{2}$, M. Fitri Rahmadana ${ }^{3}$ \\ 1,2,3Univeristas Negeri Medan, Medan - Indonesia
}

\author{
A R T I C L E I N F O \\ Article history: \\ Received November, 4 \\ 2021 \\ Received in revised form \\ November, 132021 \\ Accepted November, 20 \\ 2021 \\ Available online December, \\ 252021

\section{Kata Kunci:} \\ Buklet bahan ajar, hasil \\ belajar, model siklus \\ belajar $5 \mathrm{E}$ \\ Keywords: \\ 5 E learning cycle model, \\ booklet teaching materials, \\ learning outcomes.
}

\begin{abstract}
A B S T R A CT
The purpose of this research was to determine the feasibility of booklet teaching materials based on the $5 \mathrm{E}$ learning cycle model developed in accounting subjects for class X SMK BM Panca Budi 2 Medan. The location of the research was at SMK BM Panca Budi 2 Medan, on Jalan Gatot Subroto KM 4,5. The class was class X Accounting for the 2020/2021 Academic Year. This research applied quantitative research and development with a 4-D teaching material development model (Four D Model), or 4P by Thiagjaran and Semmel (Trianto, 2013). The 4D development model consists of 4 main stages, namely: (1) define, (2) design, (3) develop, and (4) disseminate. The data analysis technique used was descriptive and inferential techniques. Based on the results of the research, the product of booklet teaching materials based on the 5E learning cycle model in accounting subjects with general journal material in class X SMK BM Panca Budi 2 Medan was feasible to use based on material expert validation with an average of $96.37 \%$ design experts, an average of $95,8 \%$ and media experts with an average of $92.9 \%$. Thus, it is suggested to teachers, especially at SMK BM Panca Budi 2 Medan to be more creative in making teaching materials.
\end{abstract}

\section{A B S T R A K}

Tujuan penelitian ini adalah untuk mengetahui kelayakan bahan ajar booklet berdasarkan 5E model learning cycle yang dikembangkan pada mata pelajaran akuntansi kelas X SMK BM Panca Budi 2 Medan. Lokasi penelitian di SMK BM Panca Budi 2 Medan, Jalan Gatot Subroto KM 4,5. Kelas tersebut adalah kelas X Akuntansi Tahun Pelajaran 2020/2021. Penelitian ini merupakan penelitian kuantitatif dan pengembangan dengan model pengembangan bahan ajar 4-D (Four D Model), atau 4P oleh Thiagjaran dan Semmel (Trianto, 2013). Model pengembangan 4D terdiri dari 4 tahapan utama, yaitu: (1) define, (2) design, (3) develop, dan (4) diffuse. Teknik analisis data yang digunakan adalah teknik deskriptif dan inferensial. Berdasarkan hasil penelitian, produk bahan ajar booklet berbasis 5E model learning cycle pada mata pelajaran akuntansi dengan materi jurnal umum pada siswa kelas X SMK BM Panca Budi 2 Medan layak digunakan berdasarkan validasi ahli materi dengan rata-rata $96,37 \%$ ahli desain, rata-rata 95,8\% dan ahli media dengan rata-rata 92,9\%. Untuk itu disarankan kepada guru khususnya di SMK BM Panca Budi 2 Medan untuk lebih kreatif dalam membuat bahan ajar.

\footnotetext{
* Corresponding author.

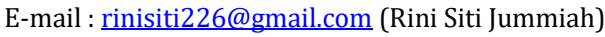




\section{Introduction}

Education is crucial and has become a necessity for everyone. In the National Education System Law Number 20 of 2003, it is explained that "humans need education in their lives, education is an effort so that humans can develop their potential through the learning process or in other ways, which are known and recognized by the community." According to (Djamaluddin, 2014), education is defined as "an effort that can be made by a person or group of other people to become adults or to achieve a better level of life or livelihood in a mental sense." Therefore education is a process that is carried out so that changes occur in people who carry out the educational process. In addition, it also means a process to build a nation and country so that quickly or not a developing country is very dependent on the existing education, due to education plays an important role in shaping the character, personality, knowledge, skills, and human behavior itself to build a country. In order for education to run smoothly and effectively, the education system has several educational components; according to Syahfril (2017), educational components such as educational goals, students, educators, learning materials, student learning outcomes, academic environment, and learning tools in the educational process. Each element has its function, and each component of education is interrelated to create an adequate education according to the existing curriculum.

From the preliminary observation, there were several problems in class X SMK BM Panca Budi 2 Medan. the identification of the problems was the lack of availability of student hence handbooks does not meet the needs of students so that the learning process does not run effectively. in addition, student accounting learning outcomes did not reach the minimum mastery for criteria, and the learning process is still teacher-centred so that students are passive in the learning process. Learning outcomes are one of the components of the existing education system. Student learning outcomes are the level of success or mastery of students in learning that has been carried out during the teaching and learning process occurs in the form of values in several subjects. In addition, learning outcomes have an essential role in student education, where learning outcomes measure the level of success of students during the existing learning process. Therefore, learning outcomes are significant for students in the world of education. However, to achieve success in learning, several factors must be considered, such as students' understanding of the concepts of the lessons presented, the availability of textbooks used by students and supporting media in learning, and the methods teachers use in delivering knowledge.

The teacher's creativity is tested more to make the learning process continue without a textbook. Maybe some teachers only provide learning through power points or by photocopying some learning materials, especially in accounting learning where this learning is more about journalizing every transaction; some even apply bookkeeping first and then an explanation. Imagine how inefficient it is in learning to account if it has to be like that. Students are a little uninterested and have no more motivation to be enthusiastic in the learning process. It is not yet fully effective in the learning process. There must also be textbooks or things like books held by the student to study at home, not just waiting for the teacher to give lessons. Without realizing something like that can affect the learning process and learning outcomes that have been determined. Several teaching materials can substitute for books that students can make or use in the learning process, such as booklets. According to Sukmawati et al. (2018) "Booklets contain important information, a booklet's contents must be clear, firm, easy to understand and will be more interesting if pictures accompany the booklet." The booklet is informative; its attractive design can easily arouse curiosity to understand what is conveyed in the learning process. Thus booklets can motivate students to be enthusiastic about learning both at school and home. If students are interested and have high motivation to participate in the learning process, the learning objectives will automatically be achieved optimally and following what has been determined. This is in line with the research of Sukmawati et al. (2018), where the development of booklet teaching materials developed in their research can improve student learning outcomes and attract students' interest to participate in the learning process.

The Learning Cycle learning model is one of the models that can be implemented to be applied in the learning process together with existing teaching materials, so that the learning objectives can be achieved more optimally. According to Sagdic, M, et al (2020) "The 5E model, which is based on the individual-centered learning in the learning-instruction process, could be used to increase the meaningful learning levels in the abstract acquisition-based study fields. It could be argued that the social studies education field is suitable for the implementation of all phases of this cycle since it includes multidisciplinary knowledge, skills and values". The learning cycle learning model is student-centered learning and emphasizes student experience in the basic concepts of learning so that students are given conflicting problems related to learning so that students are able to build their own knowledge and 
understanding. According to Taufiq, M (2012) "The 5E Learning Cycle Model is a student centered learning model which consists of activity stages (phases) namely engagement, exploration, explanation , elaboration, and evaluation"

This research aims to determine the feasibility of booklet teaching materials based on the $5 \mathrm{E}$ learning cycle model developed in accounting subjects for class X SMK BM Panca Budi 2 Medan. This research is significant both theoretically and practically. Theoretically, for the availability of booklet teaching materials based on the 5E learning cycle model able to improve student learning outcomes and provide information on student learning outcomes in accounting. Practically, this research can provide new experiences for researchers related to developing booklet teaching materials based on the learning cycle model to improve student learning outcomes. In addition, this research helps the teachers to be more creative in the use of teaching materials if the school does not provide books.

\section{Method}

This research was quantitative research and development (Research and Development) with a 4-D model of teaching materials development (Four D Model), or 4P by Thiagjaran and Semmel (Trianto, 2013). This development research is oriented towards product development at each stage. The effect of these teaching materials can produce teaching materials that are valid, effective, and understandable by many people. The final product of this development research is teaching materials in the form of booklets containing accounting materials. This research was carried out at the SMK BM Panca Budi 2 Medan, located at Jalan Gatot Subroto KM 4,5. The class was class X Accounting for the 2020/2021 Academic Year.

The population was all students of class X Accounting at SMK BM Panca Budi 2 Medan for the academic year 2020/2021. It consisted of 2 classes, namely, class X AK1 and X AK2 totaling 87 students, and the object of this research was the development of model-based booklet teaching materials. They were learning cycle with primary accounting material. This study has two objectives: developing booklet teaching materials based on the learning cycle model and testing the product's effectiveness in achieving the predetermined goals.

The process of developing booklet teaching materials in this study refers to the Thiagjaran and Semmel development model (Trianto, 2013), with the 4-D teaching material development model (Four D Model). The 4D development model consists of 4 main stages, namely: (1) define, (2) design, (3) develop, and (4) disseminate.

To test the booklet, teaching materials based on the $5 \mathrm{E}$ learning cycle model that has been developed are feasible or not; therefore, the analysis used is quantitative descriptive analysis. The data were analyzed with descriptive statistical techniques, which are quantitatively separated by category to conclude. The percentage of data obtained from the results of the questionnaire assessment was examined by the formula, as follows:

Percentage $=\frac{\text { total score earned }}{\text { Total Ideal Score of All Items }} \times 100 \%$

From the results of calculations using this formula, the resulting number is a percent (\%). The score classification will then be converted into a classification in the form of a percentage Sugiyono (2013). The criteria for determining the level of feasibility of the products that have been developed are as follows:

Table 1. Criteria for Product Feasibility Level

\begin{tabular}{cll}
\hline No & \multicolumn{1}{c}{ Criteria } & \multicolumn{1}{c}{ Percentage (\%) } \\
\hline 1 & Very feasible & $81 \% \leq \mathrm{x} \leq 100 \%$ \\
2 & Feasible & $61 \% \leq \mathrm{x} \leq 80 \%$ \\
3 & Less feasible & $41 \% \leq \mathrm{x} \leq 60 \%$ \\
4 & Not feasible & $0 \% \leq \mathrm{x} \leq 40 \%$ \\
\hline
\end{tabular}




\section{Result and Discussion}

\subsection{Data Description of Expert Validation of Booklet Teaching Materials}

The material validator on the booklet teaching material product based on the $5 \mathrm{E}$ learning cycle model is carried out by a material expert. The purpose of this material expert validation is to measure the level of accuracy and quality of the material presented in the booklet teaching material product, namely accounting subjects. In addition, the purpose of this material expert validation is to obtain a feasible product from every aspect. In general, the material expert's assessment questionnaire consists of 3 aspects, namely aspects of guidance and information, booklet teaching materials, and evaluation.

\subsubsection{Individual Trial Results Data}

Individual trials were conducted in Class X SMK BM Panca Budi 2 Medan. Subjective tests were conducted on three students of class X consisting of 1 student who has high achievement, one who has moderate achievement, and one who has the low achievement. The purpose of this individual trial is to identify the shortcomings of learning products after being reviewed by experts. The assessment and input from this trial are about the presentation of learning outcomes, including content feasibility, presentation feasibility, and language feasibility contained in the development of booklet teaching materials based on the $5 \mathrm{E}$ learning cycle model. The results of individual trials from 3 students in class X SMK BM Panca Budi 2 Medan on the development of booklet teaching materials based on the learning cycle model in accounting subjects from the aspect of content feasibility which as a whole "Very Good" criteria with a percentage of $94.7 \%$. Meanwhile, from the part of the feasibility of the overall presentation, the result was in "Very Good" criteria with a percentage of $95.6 \%$, and the general language feasibility aspect also was in "Very Good" criteria with a percentage of $97.8 \%$.

\subsubsection{Small Group Trial Results Data}

Small group trials were also conducted in class X SMK BM Panca Budi 2 Medan. Small group trials were conducted on nine students consisting of 3 high achievers, three medium achievers, and three low achievers. This small group trial data was to discover some of the weaknesses or obstacles faced when the learning cycle model-based booklet teaching material was used. From the results of trials on nine students in individual tests in class X SMK BM Panca Budi 2 Medan on the development of booklet teaching materials based on the learning cycle model in accounting subjects from the aspect of content feasibility which as a whole is stated in the "Very Good" criteria with a percentage by $96.9 \%$. Meanwhile, from the aspect of the feasibility of the presentation which is overall stated in the criteria of "Very good" with a percentage of $97.8 \%$, and from the aspect of the feasibility of the language which is overall stated in the criteria of "Very Good" with a percentage of $100.0 \%$. So it can be concluded that the product of booklet teaching materials based on the learning cycle model is suitable for field trials (extensive group tests) according to the recommended revision.

\subsection{Field Trial Result Data}

Field trial was in Class X SMK BM Panca Budi 2 Medan. The students of class X SMK BM Panca Budi 2 Medan consisted of 45 students. Field trials produce data that will later measure the feasibility of the product being developed and find out how the benefits of the product are for the user. The results of the evaluation of learning media on the aspect of content feasibility from 45 students in the field trial in class X SMK BM Panca Budi 2 Medan on the development of teaching materials based on the learning cycle model of accounting subjects as a whole stated in the "Very Good" criteria with a proportion of $99.6 \%$. Meanwhile, the aspect seen as a whole is stated in the "Very Good" criterion with a proportion of $99.1 \%$ and the language-appropriate aspect stated in the "Very Good" criterion with a proportion of $99.6 \%$. So it can be said that this cycle model-based learning booklet product is very feasible to use according to the recommended revision.

\subsection{Data Analysis of Learning Material Expert Assessment}

Based on the data from material expert validation, it is known that the material aspect of booklet teaching materials has the highest average score (98.3\%), while the guidance and information aspect has the lowest score (93.3\%) compared to other elements. In the guidance and information aspect, the material expert gave an assessment of "Very Eligible", on the booklet teaching material aspect, the material expert gave an average rating of $98.3 \%$ with a very decent category, and in the evaluation aspect, the material expert also gave an assessment "Very Worthy". It can be seen from Table 2 below. 
Table 2. Average Percentage of Assessment Results of Learning Material Experts

\begin{tabular}{cll}
\hline No & Aspect & Average (\%) \\
\hline 1 & Guide and Information & 93,3 \\
2 & Booklet Teaching Materials & 98,3 \\
3 & Evaluation & 97,5 \\
& Total average & 96,4 \\
& Category & Very feasible \\
\hline
\end{tabular}
below:

The results of the assessment of the three aspects by material experts can be seen in the diagram

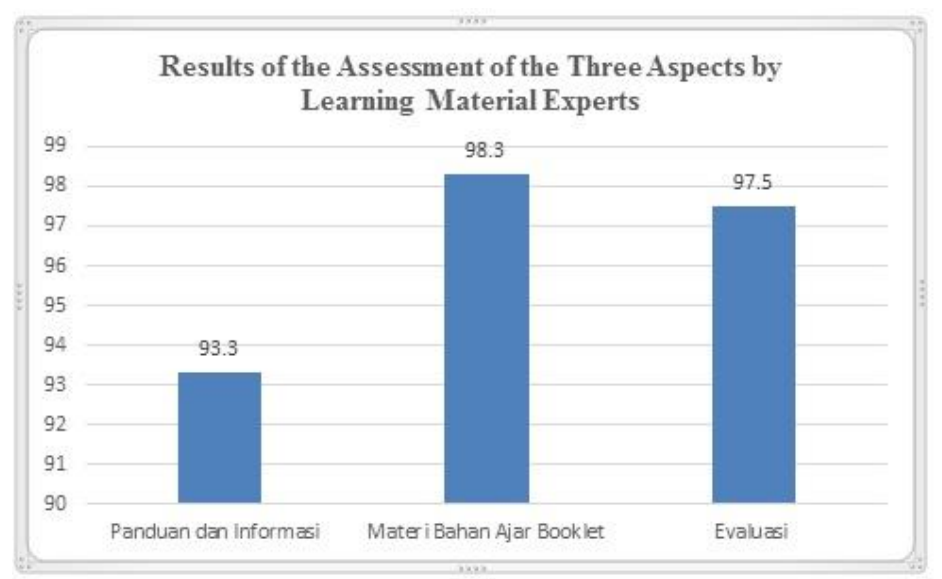

Figure 1. Bar Chart of Material Expert Assessment Results

From the figure 1, the results of the assessment of learning materials experts on booklet teaching materials based on the $5 \mathrm{E}$ learning cycle model showed an average score of $96.4 \%$, included in the "Very Eligible" category, which means that from 3 aspects that were assessed, both aspects of guidance and information, aspects of booklet teaching materials, and evaluation aspects are very in line with the learning objectives to be achieved in the learning process. Based on the responses and assessments of learning material experts, booklet teaching materials based on the $5 \mathrm{E}$ learning cycle model are feasible to be tested with revisions and suggestions given by learning material experts (Mulyadi, 2011).

\subsection{Data Analysis of Learning Design Expert Assessment}

Based on design expert validation data, the objective learning aspect has the highest average score (98.0\%), while the learning resource aspect has the lowest score (92.5\%) compared to other elements. In the introductory aspect, learning objectives, final tests, learning experiences, and learning resources, the design expert gave a "Very Eligible" assessment, as shown in table 3. below.

Table 3. Average Percentage of Assessment Results of Government Design Experts

\begin{tabular}{lll}
\hline No & Aspect & Percentage (\%) \\
\hline 1 & Introduction & 95,0 \\
2 & Learning goal & 98,0 \\
3 & Final test & 95,0 \\
4 & Learning experience & 96,0 \\
5 & Learning sources & 92,5 \\
& Total average & 95,8 \\
& categori & Very worthy \\
\hline
\end{tabular}

The results of the assessment of the five aspects by visual learning design experts can be seen in the diagram below: 


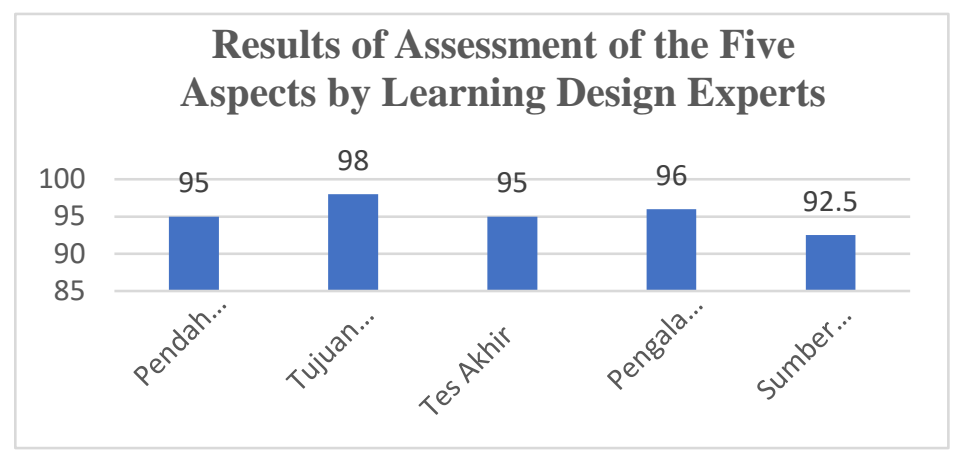

Figure 2. The Bar Chart Design Expert Assessment Results

The assessment results of learning design experts on booklet teaching materials based on the $5 \mathrm{E}$ learning cycle model that was developed showed an average score with a value of $95.4 \%$, included in the "Very Eligible" category. It means that from 5 aspects that were considered, both preliminary aspects, aspects of learning objectives, aspects of the final test, aspects of learning experiences, and aspects of learning resources are very in line with the learning objectives to be achieved in the learning process. Based on the responses and assessments of learning design experts, booklet teaching materials based on the $5 \mathrm{E}$ learning cycle model are very feasible to be tested with revisions and suggestions that have been given by learning design experts (Lubis, 2019b).

\subsection{Learning Media Expert Assessment Data Analysis}

The data obtained from learning media experts on the design aspect of the booklet skin (cover) shows that the booklet teaching materials are very feasible to use with an average of $93.3 \%$. In the design aspect of the booklet content, the overall average score of $92.5 \%$. It means very feasible. From these results, the average assessment of learning media experts as a whole is $92.9 \%$. It was "very feasible". This can be seen in table 4., below:

Table 4. Results of Assessment of Learning Media Experts on Both Aspects

\begin{tabular}{lll}
\hline No & Aspect & Average Score (\%) \\
\hline 1 & Cover & 93,3 \\
2 & Booklet Content Design & 92,5 \\
& Total average & 92,9 \\
& Category & Very feasible \\
\hline
\end{tabular}

The results of the assessment of the two aspects of evaluation by learning media experts can be seen visually in the diagram below:

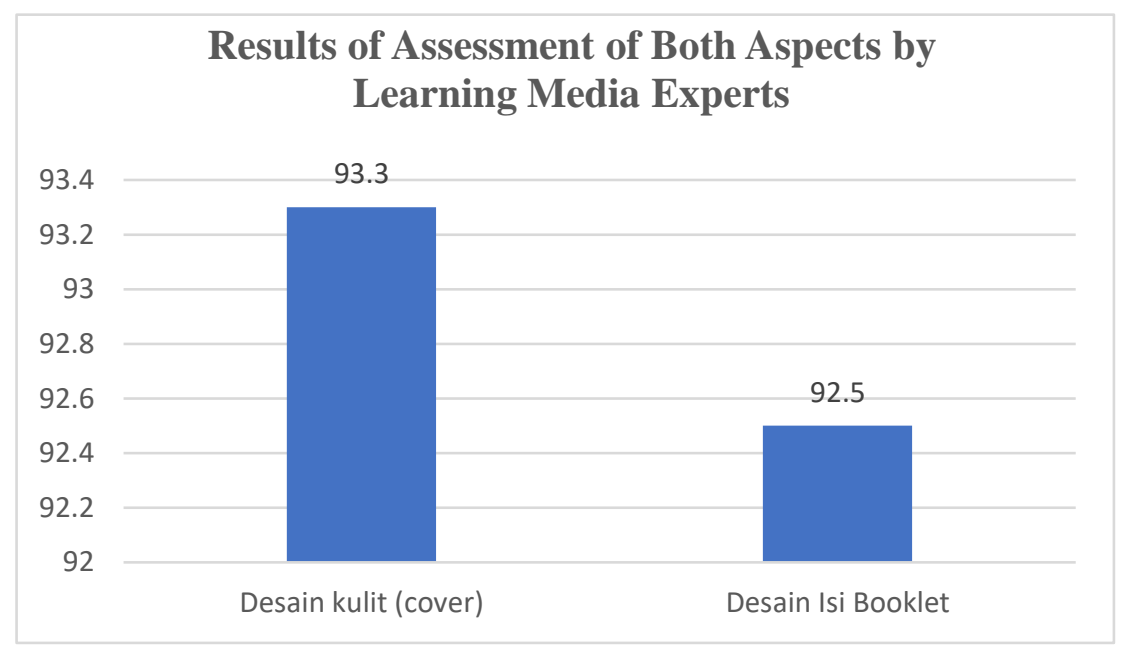

Figure 3. Bar Chart of Learning Media Expert Assessment Results 
Based on the data from the validation results of the learning media experts above, it is known that the design aspect of the booklet skin has an average score of $93.3 \%$. In comparison, the design aspect of the booklet content based on the 5E learning cycle model has a score of $92.5 \%$. Thus, it can be concluded that the product of booklet teaching materials is very suitable to be used for field trials with recommended revisions.

\subsection{Data Analysis of Individual Trial Results}

This individual trial was conducted to find out the shortcomings of the booklet teaching materials based on the 5E learning cycle model before conducting a small group trial. The overall average score of the three aspects is 96.0 which is qualitatively categorized as "very decent" (X 81\%). The following is a table of individual trial assessments on the three aspects of the evaluation:

Table 6. The Results of the Individual Trial Assessment of the Three Aspects

\begin{tabular}{lll}
\hline No & Aspect & Average Score (\%) \\
\hline 1 & Content Eligibility & 94,7 \\
2 & Serving Eligibility & 95,6 \\
3 & Serving Eligibility & 97,8 \\
& Total average & 96,0 \\
& category & Very feasible \\
\hline
\end{tabular}

The results of the individual trial assessment on the three aspects can be seen visually in the diagram below:

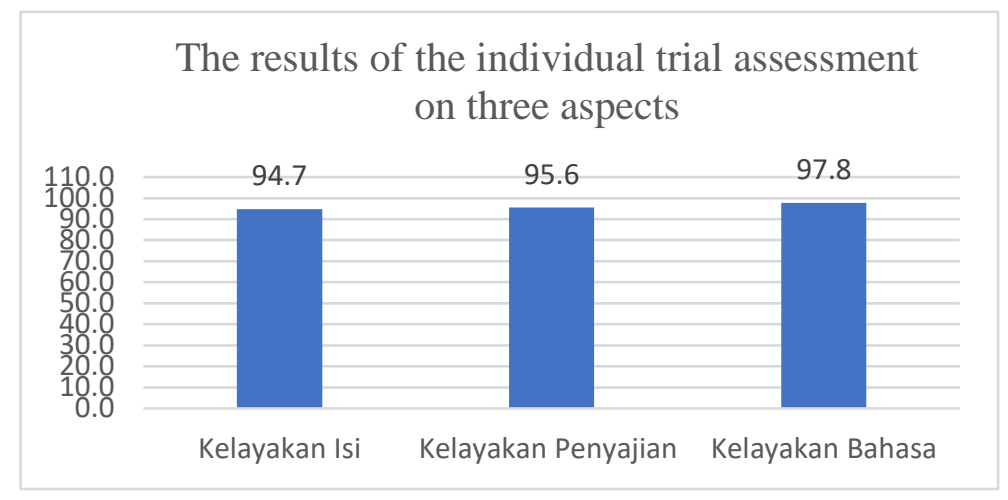

Figure 4. Bar Chart of Individual Trial Assessment Results

\subsection{Data Analysis of Small Group Trial Results}

Based on the assessment table of the results of the small group test by 9 students on these three aspects, it can be concluded that the product of booklet teaching materials based on the learning cycle model is very suitable to be used for field trials (extensive group tests) following the recommended revision. The overall average score of the three aspects is 98.2 which is qualitatively categorized as "very decent" (X 81\%). The following table presents the assessment of the small group test on the three aspects of the evaluation:

Table 7. The Results of the Small Group Trial on the Three Aspects

\begin{tabular}{lll}
\hline No & Aspect & Average Score (\%) \\
\hline 1 & Content Eligibility & 96,9 \\
2 & Serving Eligibility & 97,8 \\
3 & Serving Eligibility & 100,0 \\
& Total average & 98,2 \\
& category & Very feasible \\
\hline
\end{tabular}

The results of the small group test assessment on three aspects can be seen in the diagram below: 


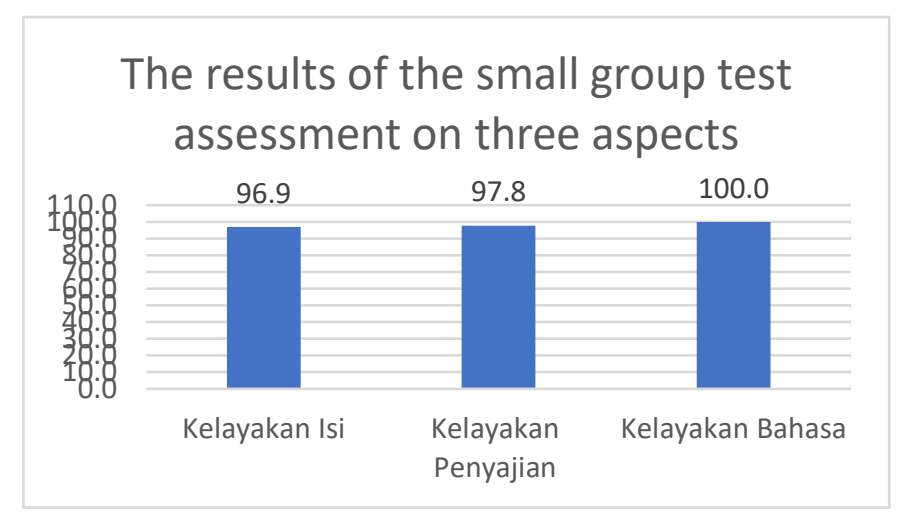

Figure 8. Bar Chart of Small Group Trial Assessment Results

\subsection{Data Analysis of Field Trial Results}

In this field trial, it is known that the overall average score of the three aspects is 99.4. It is "very feasible" (X 81\%). The following table presents the field trial assessment on the three elements of the evaluation:

Table 8. Results of Field Trial Assessment on the Three Aspects

\begin{tabular}{lll}
\hline No & Aspect & Total score (\%) \\
\hline 1 & Content Eligibility & 99,6 \\
2 & Serving Eligibility & 99,1 \\
3 & Serving Eligibility & 99,6 \\
& Total average & 99,4 \\
& Category & Very feasible \\
\hline
\end{tabular}

The results of the field trial assessment on three aspects can be in the diagram below:

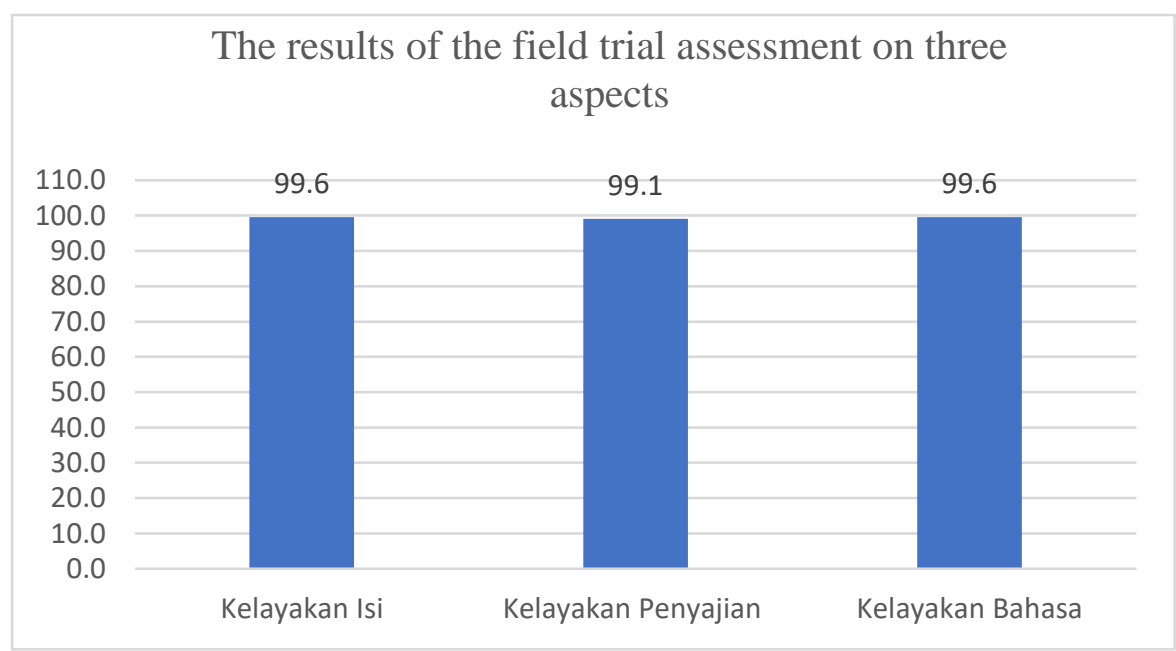

Figure 9. Bar Chart of Field Trial Assessment Results

Based on the validation results that have been done, the booklet teaching materials based on the 5E learning cycle model are very feasible to use, and field trials can be carried out. Booklet teaching materials are based on the 5E learning cycle model. This product development research was carried out at SMK BM Panca Budi 2 Medan in class X accounting, where the product development of teaching materials was developed for the learning outcomes obtained by students and providing benefits for the students themselves. This is in line with the opinion expressed by Atiko (2019) that the help of the booklet teaching materials is (1) Creating confidence. The completeness of the content and very detailed information make students' perceptions positive. (2) Promote to friends. Giving a booklet to one student can make other students curious. Students will read booklets with friends and other closest people. (3) Don't get bored 
while reading it. Students feel interested in reading the booklet to completion because the design and appearance of the booklet are not dull. And excellent language and pictures make it easier for students to understand the learning material provided (Lubis, 2019a).

Product Feasibility Test Results During the process of implementing learning using a booklet based on the 5E learning cycle model, it helps increase student interest in participating in the existing learning process, this is because the booklet itself is designed very attractively, full of colors and illustrated pictures that can foster student curiosity. To open and start. Suppose students are interested in the existing learning process. In that case, the booklet is feasible to assist students in the learning process. The learning outcomes obtained will increase, and the quality of the existing learning process will rise (Shaumiwaty et al., 2020).

Based on the validation results that have been obtained from existing experts, therefore the validation results from material experts in the development of accounting teaching materials in the form of booklets based on the learning cycle model for students show that in the aspects of guidance and information with an average of $93.3 \%$, on very feasible criteria where this information guide aspect provides clear information related to the competencies to be achieved by students during the learning process, the feasibility of booklet teaching materials with an average of $98.3 \%$ on every feasible criteria, where the material contained in the material teaching is adjusted to the curriculum, conformity with learning objectives, and the material presented is very easy to understand, and in the evaluation aspect with an average of $97.5 \%$ on very decent criteria, in this aspect the evaluation used is not only essay questions but is given a variety of questions One of them is a multiple-choice question (Borg \& Gall, 2007).

Thus, the booklet teaching materials based on the learning cycle model developed as a whole are included in the "very feasible" criteria. This is in line with the eligibility criteria according to Sugiyono (2013), among others:

Table 9. Product Eligibility Level Criteria

\begin{tabular}{lll}
\hline No & Criteria & Percentage (\%) \\
\hline 1 & Very feasible & $81 \% \leq x \leq 100 \%$ \\
2 & Feasible & $61 \% \leq x \leq 80 \%$ \\
3 & Less feasible & $41 \% \leq x \leq 60 \%$ \\
4 & Not feasible & $0 \% \leq x \leq 40 \%$ \\
\hline
\end{tabular}

The validation results from design experts on the feasibility of the design in the development of booklet teaching materials based on the learning cycle 5E model for students who developed indicate that the preliminary aspect has an average percentage of $95.0 \%$ on the very feasible criteria, which in this aspect provides instructions for working on easy questions. understood by students, the element of learning outcomes has an average percentage of $98.0 \%$ on the very feasible criteria, on the final test aspect with an average of $95.0 \%$ on the very feasible criteria, on the learning experience aspect students have an average percentage $96.0 \%$ on very decent criteria, in this aspect the material presented is related to learning experiences and their daily experiences so that the process of delivering material can be easily understood by students, in the element of learning resources students have an average percentage of $92.5 \%$ on very decent criteria, in this aspect the source of learning is only from the opinions of the experts, but learning resources obtained from several well-indexed journals. The average percentage result of all sub-components of the design feasibility assessment is $95.8 \%$ with the "very feasible" criteria. Thus, the feasibility of designing booklet teaching materials based on the 5E learning cycle model that was developed can be used as a design pattern that students will use.

Overall, both in terms of material presentation, in terms of teaching material design, language used, sample questions, and materials contained in booklet teaching materials based on the 5E learning cycle model, which was developed and following the guidelines and assessment criteria according to Sugiyono (2013), it can be concluded that Booklet teaching materials based on the 5E learning cycle model in accounting subjects are suitable for use in the learning process. The average proportion of all subcomponents assessing the design is $95.8 \%$ with the "very feasible" criteria. Thus, the design of teaching materials based on the cycle $5 \mathrm{E}$ learning model developed can be used as a design pattern that students will use. Both in terms of material presentation, the design of teaching materials, the language used, sample questions, and the material contained in the booklet based on the cycle five learning model, which was developed following the guidelines and assessment criteria according to Sugiyono (2020), it can be said that the material booklet teaching based on the $5 \mathrm{E}$ learning cycle model on accounting subjects that are suitable for use in the learning process. 
According to data analysis, student learning outcomes in accounting subjects taught using booklet teaching materials based on the 5E learning cycle model increased from an average pretest gain of 62.22 to an average value of 87.04 after being taught using booklet teaching materials based on the $5 \mathrm{E}$ learning cycle model. This increase in understanding can occur as a result of students completing training activities independently or in groups using booklet teaching materials based on the Learning Cycle 5E model of general journal materials that are organized in a simple manner. The developed booklet's advantages include the following: it contains critical information that is very clear and easy to understand, as well as a large number of practice questions that are relevant to the existing learning objectives. Additionally, the booklet's presentation incorporates numerous illustrations and colors to create an attractive appearance that can pique students' interest in learning. Students will be motivated to learn the material through engaging practice activities, and will be able to complete practical activities because they are equipped with activity steps and a summary of the material. Thus, students will have authentic experiences that will stick with them.

The summary of the material is tailored to the students' ability level through the use of simple language, making it easy for students to comprehend and pique students' interest in learning. The development of booklet teaching materials based on the 5E model of learning in general journal materials demonstrates that student learning outcomes improve and students become more engaged in their learning. It has been established that post-test results increased in comparison to pre-test results. As evidenced by the learning outcomes of students taught using booklet teaching materials based on the $5 \mathrm{E}$ learning cycle model, with an average (mean) pre-test score of 62.2287 .04 , it can be concluded that booklet teaching based on the 5E learning cycle model in accounting subjects with general journal material is significantly effective in improving student learning outcomes in accounting subjects for class $\mathrm{X}$ SMK BM Panca Budi 2 Medan.

\section{Conclusion and Suggestion}

Based on the research results, the development of booklet teaching materials based on the learning cycle model in accounting subjects for class X SMK BM Panca Budi 2 Medan showed the product of booklet teaching materials meet the requirements. It is also suitable for use based on expert validation of materials including guides and information, booklet teaching materials based on the 5E learning cycle model, and evaluation with an average of $96.37 \%$ on very feasible criteria. Based on expert validation, the five aspects of the design expert's assessment obtained an average of $95.8 \%$ with very feasible criteria and media expert validation with an average of $92.9 \%$ on very feasible standards. The teachers suggest that they should be more creative in making teaching materials and need to learn how to create exciting materials, not just photocopies. Still, they must follow the development of the existing learning process so that learning is not monotonous and boring. Further, the product development developed with broader materials or materials that have never existed by using other approaches under the characteristics of students and learning materials.

\section{References}

Atiko. (2019). Booklet, Brosur dan Poster Sebagai Karya Inovatif di Kelas. Caremedia Communication.

Borg, W. R., \& Gall, M. D. (2007). Educational research: an introduction. Longman Inc.

Djamaluddin, A. (2014). Filsafat Pendidikan. Istiqra: Jurnal Pendidikan Dan Pemikiran Islam, 1(2).

Lubis, T. (2019a). Learning Nandong in schools as a medium to inform the Simeuluenese local wisdom: An anthropolinguistics approach. Studies in English Language and Education, 6(2), 262-272.

Lubis, T. (2019b). Participant Structure in Learning English: Linguistic Anthropology Approach. 4th Annual International Seminar on Transformative Education and Educational Leadership (AISTEEL 2019), 571-573.

Mulyadi. (2011). Penelitian Kuantitatif dan Kualitatif serta Pemikiran Dasar Menggabungkannya. Jurnal Studi Komunikasi Dan Media, 15(1), 127-138.

Shaumiwaty, S., Lubis, M. A., Lubis, T., Dardanila, Purba, A., Nasution, T., Ramlan, \& Hasrul, S. (2020). Teacher performance toward students' mathematical literacy in teaching linear program mathematical models. Journal of Physics: Conference Series, 1663, 012066.

Sugiyono. (2013). Metode Penelitian Kuantitatif Kualitatif dan R \& D. Alfabeta.

Sugiyono. (2020). Metode Penelitian Kualitatif. Alfabeta.

Sukmawati, S. S., Nursulistyo, E., \& Oktaviyanti. (2018). Pengembangan bahan ajar booklet untuk 
meningkatkan hasil belajar pokok bahasan momentum untuk siswa kelas X semester 2 SMAN 4 Yogyakarta. Seminar Nasional Fisika, Dan Pendidikan Fisika, 53-60.

Syahfril. (2017). Dasar-dasar Ilmu Pendidikan. Kencana.

Trianto. (2013). Mendesain Model Pembelajaran Inovatif, Progresif, Konsep, Landasan, dan Implementasinya Pada Kurikulum Tingkat Satuan Pendidikan (KTSP). Kencana Prenada Media Group. 